\title{
Hegel's Justification of the Human Right to Non-Domination
}

\begin{abstract}
Hegel' and 'human rights' are rarely conjoined, and the designation 'human rights' appears rarely in his works. Indeed, Hegel has been criticised for omitting civil and political rights all together. My surmise is that readers have looked for a modern Decalogue, and have neglected how Hegel justifies his views, and hence just what views he does justify. Philip Pettit (1997) has refocused attention on republican liberty. Hegel and I agree with Pettit that republican liberty is a supremely important value, but appealing to its value, or justifying it by appeal to reflective equilibrium, are insufficient both in theory and in practice. By reconstructing Kant's Critical methodology and explicating the social character of rational justification in non-formal domains, Hegel shows that the republican right to non-domination is constitutive of the equally republican right to justification (Forst 2007) - both of which are necessary requirements for sufficient rational justification in all non-formal domains, including both claims to rights or imputations of duties or responsibilities. That is the direct moral, political and juridical implication of Hegel's analysis of mutual recognition, and its fundamental, constitutive role in rational justification. Specific corollaries to the fundamental republican right to non-domination must be determined by considering what forms of illicit domination are possible or probable within any specific society, in view of its social, political and economic structures and functioning.
\end{abstract}

Keywords: Hegel, human rights, non-domination, Pettit, republicanism, justification, recognition

\section{Introduction.}

'Hegel' and 'human rights' are rarely conjoined; the designation 'human rights' appears seldom in his works. Indeed, Hegel has been criticised for omitting civil and political rights all together. My surmise is that many of his readers have sought some modern counterpart to a Decalogue, and have neglected how Hegel justifies his views, and hence just what views he does justify. Philip Pettit (1997) has refocused attention on republican liberty. Hegel and I agree with Pettit that republican liberty is a supremely important value, but justifying it by appeal to its value, to reflective equilibrium or to human psychology (Pettit 1997, 2001) are insufficient both in theory and in practice. By reconstructing Kant's Critical methodology and explicating the social character of rational justification in non-formal domains, Hegel shows that the republican right to non-domination is constitutive of the

Kenneth R. Westphal: Department of Philosophy, Boğaziçi Üniversitesi in İstanbul; westphal.k.r@gmail.com. 
equally republican right to justification (Forst 2007, 2011) - both of which are necessary requirements for sufficient rational justification in all non-formal domains. That is the direct moral, political and juridical implication of Hegel's analysis of mutual recognition and its fundamental, constitutive role in rational justification. Specific corollaries to the fundamental republican right to non-domination must be determined by considering what forms of illicit domination are possible or probable within any specific society, in view of its social, political and economic structures and their functioning.

To examine these issues about justice, justification and human rights, I ignore the still resounding din of the Hegel mythology (Kaufmann 1951, Stewart 1996) and omit summary of my previous findings regarding Hegel's republicanism in his Philosophical Outlines of Justice (Grundlinien der Philosophie des Rechts, 1821; 'Rph'). ${ }^{1}$

Hegel's Philosophical Outlines of Justice is perhaps the most ardent, systematic, cogently justified analysis of (small ' $r$ '!) republicanism possible. This is not a fact he could then and there trumpet: in 1792 Prussian censors blocked publication of Wilhelm von Humboldt's quintessentially liberal tract, The Limits of State Action; in 1831 they interdicted mid-way the publication of Hegel's (1831) searching analysis of the English reform bill. However politely they may have explained their interdiction, the censors can hardly have missed how Hegel's magisterial contrast, between progressive Continental constitutional reform and the stagnation of entrenched feudal interests and constraints in England, held equally well of the entrenched feudal relics and sclerotic interests ruling Prussia - topics of Hegel's earliest writings in political philosophy (Hegel 1798a, 1798b (ms.), 1799-1803 (ms.); cf. idem. 1817, Falkenheim 1909²).

\section{Focussing the Issue of Justification.}

Republican liberty in the form of non-domination is central to Rousseau's independence requirement, viz.: that no one be allowed to obtain nor to wield the kind or extent of power, wealth or privilege to command unilaterally the choice or action of anyone else (Neuhouser 2000, 55-81; Westphal 2013a). Rousseau's independence requirement is directly adopted and augmented by Kant's explication of the sole innate right to freedom (MdS 6:237). Kant's declaration of this sole innate right may appear to be no better justified than the purportedly self-evident truths exalted by the US Declaration of Independence. The history of political appeals to self-evidence shows that in any

1 See Neuhouser (2000), Conklin (2008), Westphal (forthcoming).

2 Falkenheim (1909) first identified Hegel as the translator and commentator to J.J. Cart's anonymous letters. 
substantive domain, 'self-evidence' provides the mere appearance of rational justification. Kant does justify his sole innate right to freedom; Hegel further explicated, undergirded and augmented Kant's justification of the sole innate right to freedom. To appreciate the point, character and cogency of their justification of the sole innate right to freedom - including constitutively the republican freedom from domination and the equally republican right to justification - first requires characterising the weaknesses of other popular justifications.

Pettit $(1997,2001)$ certainly is correct that in practice non-domination has important social-psychological dimensions, that we need not fear others, but instead can engage with others - any and all others - as moral equals. I agree emphatically that this kind of self-respect is morally, politically and psychologically valuable, indeed decisively so. However, no appeal to psychology alone can justify the 'value' or the ideal(s) of non-domination, not, at least, until we have a sound and credible psychological theory to distinguish in principle and in practice between moral mental health and immoral sociopathy or arrogant egoism. Those bent on domination find it psychologically crucial to their own self-understanding, and very much worth their own while to dominate others. Alice Miller (1981-2005) has worked brilliantly to expose the psychological defects and effects of such domineering personalities, and to make their identification and preliminary diagnosis possible for a wide range of public officials, teachers, advisors to youth and mental health workers. Perhaps our most serious political problem is to understand why such domineering personalities so easily find willing political audiences. When we met in 1987, Kurt Schmidt - a German economist old enough to have been in Hitler youth, yet young enough not to have been sacrificed in Hitler's final delusion, the Volkssturm - put it to me this way: 'Every population has its 3-4\% crazies; we need to worry when others start listening to them'. Little in this problem is specifically philosophical. One philosophical aspect of this problem concerns the institutions required to prevent democracy from deteriorating into demagoguery. Another philosophical aspect of this problem concerns the philosophy of education required to construct and conduct education at all levels so as to prepare young adults to become, and then to beby conducting themselves as - competent holders of that vital public office, the office of citizen (Green 1999, Curren \& Metzger 2016, Westphal 2016e). Both of these points are justified by, and are required for, the republican rights to non-domination and to justification, both in theory and in practice.

\section{Two Popular Failures of Justification.}

To appeal to 'values', to 'ideals' or to some model of psychological health as a major premiss used to identify or to justify basic moral principles, however 
natural such appeals may seem, is in principle insufficient, because any reasoning based upon those premises can only address whomever happens to share those premises. This is another, more general version of the problem already mentioned about appeals to 'self-evidence': In matters moral we most urgently need to secure both justification and, ultimately, agreement and acceptance in precisely those issues where disagreements arise most sharply, where these disagreements are often framed in terms of different supreme values, ideals, or models of healthy, decent, flourishing or pious individual lives. Preaching only to the converted cannot address divisive issues.

Rawls (1971) - or rather his avid converts - popularised appeal to 'reflective equilibrium': examining and re-examining our most considered principles and their relation(s) - or lack thereof - to our most considered particular moral judgments (or 'intuitions'), so as to adjust these mutually to obtain a maximally satisfactory set of moral principles linked to specific moral judgments, and then to use these to address issues of distributive justice. Despite its popularity - it is also used by Pettit's republicanism (1997, 11, 102, 106, $130,275)$ - 'reflective equilibrium' is not a method, much less a method of justification, for four reasons: (1) Achieving reflective equilibrium is a conditio sine qua non for holding a coherent - that is, a consistent and integrated - view, but coherence alone cannot justify any view, and especially not one regarding any controversial domain. (2) Nothing in this presumed 'method' of reflective equilibrium indicates how to distinguish between better or worse, sufficient or insufficient results of mutually accommodating principles and specific judgments. (3) Nothing in this presumed method of reflective equilibrium indicates how or why any two people, starting even with identical sets of principles and specifics, should equilibrate to the same coherent results, and so be led to argue for the same policy priorities. (4) This so-called 'method' indicates neither how nor how best to achieve sufficient agreement about any one coherent view, so as to use that agreement to justify credible consequences (implications, conclusions, policies) for any doubtful or controversial issue, not even amongst those who happen to share largely the same principles and specific judgments (or 'intuitions'). Quite simply and literally, 'reflective equilibrium' simply is not a method.

Rawls (1971, 20 n.7) borrowed his coherentism from Goodman's claim about rules of inference and inferential practice, whether deductive or inductive; Goodman stated:

A rule is amended if it yields an inference we are unwilling to accept; an inference is rejected if it violates a rule we are unwilling to amend. The process of justification is the delicate one of making mutual adjustments between rules and accepted inferences; and in the agreement achieved lies the only justification needed for either. (Goodman 1955, 64) 
Goodman's formulation expressly concerns what we (purportedly) do, namely, that we trim specifics to fit our principles, and trim our principles to fit specifics. Nothing in his observations show that we ought to do this, nor how we ought best or even properly to do this. Thus his remarks neither provide nor suggest any justificatory method. Goodman's claim does nothing to link what we are willing or unwilling to accept, reject or amend to what we should be (un)willing to accept, reject or amend, nor to explicate how we ought best to make such adjustments. Hence Goodman's remarks provide no method, and certainly no method of justification. Goodman's mutual trimming of rules and inferences, or analogously of theory and data, is an exercise in conventionalism, nothing more (cf. Westphal 2015).

Perhaps such mutual trimming might be credible regarding empirical knowledge, where our claims, principles, theories and explanations must contend with natural fact and circumstance - though one of coherentism's prime contemporary exponents, Laurence Bonjour (1997), finally conceded to Susan Haack that coherence does not suffice for justification even within the domain of empirical knowledge. Yet even that apparent empirical advantage lacks a credible counterpart within the moral domain. Moral 'intuitions' are insufficiently well-ordered to ground stable equilibria (Perlmutter 1998), and there are deeply and apparently irreconcilable 'intuitions' (if indeed that is what they are) amongst (schools of) philosophers. ${ }^{3}$ Thus reflective equilibrium as such can scarcely avoid (sub-)cultural or historicist relativism; instead it may indeed be a source - if not an instance - of it. 'Reflective equilibrium' may be the best for which we can initially strive in highly problematic domains; it may be a conditio sine qua non for any tenable view, but even in fraught domains our goals must include devising genuine justificatory methods or criteria for the domain in question. 'Reflective equilibrium' does not suffice for justification because, as Griffin $(1996,124-5)$ noted, it says so very little (cf. Daniels 1996, 333-52).

Now Rawls does have a method, but that method lies in his elaborate use of the veil of ignorance and its progressive lifting. This method, however, cannot identify or justify basic moral principles, because his method presumes prevalent agreement about liberal fundamentals of distributive justice. If this feature becomes more pronounced in his later writings, it is already present in the first edition of his Theory of Justice, about which B.J. Diggs observed: If we asked John Rawls whose theory of justice this is, he would say, it is our theory of justice. ${ }^{4}$ Rawls' methods cannot justify the republican right to

3 On Rawls, see O’Neill (2003) and Reidy (1999, 2000).

4 Diggs made this remark in his undergraduate course in political philosophy (at the University of Illinois, Urbana-Champaign), which I had the good fortune to take (ca. 1971). I recall his observation clearly because I was surprised by it; I remain equally 
non-domination, nor the republican right to justification. For reasons first identified by Kant's Critical method, these two rights are two aspects of the sole innate right to freedom; they are presupposed, rather than justified, by any tenable form of liberalism.

To appreciate Kant's Critical insights into rational justification in substantive domains, it is important to recognise that the justificatory failures just noted about self-evidence, about values or ideals as major premises, about coherence and about reflective equilibrium are, quite literally, ancient news: They are each variations on the old sceptical wheel, paradigmatically formulated by Sextus Empiricus in the Pyrrhonian Dilemma of the Criterion. This Dilemma poses the problem of justifying criteria of truth - or likewise criteria of justification - within any disputed domain. In disputes about specific substantive issues where no answer is patently obvious, issues easily arise about how to justify whatever one adduces as relevant evidence or reasons for one's view on that substantive issue. The problem is that spelling out one's account of, or approach to, justification can easily prompt further dispute about it, thus raising issues about whether or how to justify criteria of justification, whenever justification and its methods or basis are or become controversial. Sextus states the Dilemma in terms of criteria of truth, but the same dilemma arises with regard to criteria of justification:

... in order to decide the dispute which has arisen about the criterion [of truth], we must possess an accepted criterion by which we shall be able to judge the dispute; and in order to possess an accepted criterion, the dispute about the criterion must first be decided. And when the argument thus reduces itself to a form of circular reasoning the discovery of the criterion becomes impracticable, since we do not allow [those who claim to know something] to adopt a criterion by assumption, while if they offer to judge the criterion by a criterion we force them to a regress ad infinitum. And furthermore, since demonstration requires a demonstrated criterion, while the criterion requires an approved demonstration, they are forced into circular reasoning. (Sextus Empiricus 1933, 2.4.20, cf. 1.14.116-7)

Though often mistaken for the Pyrrhonian original, Chisholm's (1982, 6177) 'Problem of the Criterion' is much simpler and far less flexible than the Dilemma of the Criterion (Westphal 1998, 2014). The Pyrrhonian Dilemma of the Criterion cannot be resolved by the typical accounts of, nor approaches to, rational justification prevalent in philosophy, and especially

puzzled today about anyone - or any group - 'owning' a distinctive theory of justice. Perhaps Diggs' observation also had in view such cold war issues as Dewey's (1938) reply to Trotsky. Such communitarianism is an unnecessary default; what I call 'Natural Law Constructivism' is much more robust, cogent and cosmopolitan (Westphal 2016a). (It may be worth noting that B.J. Diggs is amongst those Rawls (1971, xii) acknowledged for providing helpful correspondence concerning his second manuscript.) 
so in moral philosophy, where we lack uncontroversial counterparts to obvious ordinary claims which, as Pyrrhonists concede, appear indisputable, such as 'It is day', or 'I am now conversing' ( $A L$ 1:391, 2:144). If we may agree on terms, we immediately confront issues about their proper scope or designation: 'Virtue is good and vice is bad', but which traits or acts count as virtuous or vicious? 'Murder is wrong', but which killings count properly as murder? 'Respect all persons as free rational agents', but who is a person or who are people? Certainly I do not expect to refute anyone's bigotry by rational argument, but there are important considerations regarding how to identify bigotry, dogmatism, power-mongering or other forms of moral narrow-mindedness, and how to distinguish these from respectable forms of ardent, if heterodox conscientiousness.

\section{Judgment to the Rescue?}

If we focus solely upon propositions as premises in justificatory arguments, and upon their logical relations by which they are supposed to justify Someone's conclusions about principles, policies or actions, the Pyrrhonian Dilemma of the Criterion - and its lesser cousins, Chisholm's Problem of the Criterion or Williams' (1988) 'Aggripan Trilemma' - are insoluble: Either we argue in a vicious circle, we launch a pointlessly infinite regress, we presuppose what we ought to prove (petitio principii), or we regress back either to a false or to an irrelevant claim and admit defeat (cf. Alston 1989, 26-7).

However, there is much more to rational justification and to rational judgment than what we can state and analyse in our explicit premises and arguments. Frege (1879) rightly opposed psychologism: No merely descriptive account of our reasoning processes suffices to account for their validity - if indeed they are valid. Yet Frege also rightly focussed upon judgment and upon judgments, regarding their logical validity and regarding (in some contexts) their justifiedness ( $c f$. Bell 1979). Recently I read widely in late Nineteenth Century (C.E.) European philosophy, and learned just how prevalent and problematic psychologism was. ${ }^{5}$ Since then, I have also learned that these same problems were widespread within philosophy of law at the turn of the Twentieth Century, with common appeals to psycho-social history regarding the root causes and consequences of legal systems. ${ }^{6}$ Nevertheless, Carnap's

5 E.g., Brentano (1874), Lipps (1901, 1912, 1913), Wundt (1907).

6 E.g., Gareis (1911), 9-11; Gareis (1911, 5n, 40 67) notes the importance of ethical considerations, but does not sufficiently distinguish the fact of voluntary submission to legal authority, or the fact that we may feel we have such a duty, from whether or when such submission to or acceptance of a legal order may be justified. Neither do Kocourek in his editorial note to Gareis (1911, 9-11n), nor MacDonell in his 'Introduction' to Berolzheimer (1912, xxxi). Issues about psychologism are not moot; following Quine, Pattaro (2005, xxvii, 190, 364, 373, 382-3, 388-406), expects great gains for philosophy 
(1950a, \$11) strategy for avoiding psychologism - to eschew consideration of judgment altogether, and instead to focus solely upon propositions and their logical analysis - was excessive, indeed, self-undermining.

Carnap's exclusive attention to the logical analysis of concepts, their combinations (in propositions) and the inferential relations between propositions was excessive even within his own semantics, for reasons important to recall here. Carnap's case for concentrating upon logical analysis alone requires successfully distinguishing between questions 'internal' and 'external' to any linguistic framework. Carnap's linguistic frameworks are, however, conceptual explications writ large: combinations of explicated concepts and principles sufficient to formulate the logical and physical laws for some domain of scientific inquiry. The problem is that assessing whether or in what regard(s) any explicatum improves upon its explicandum requires assessing whether or the extent to which the explicatum functions better within the context of its original, by better facilitating that scientific inquiry or explanation. Such assessment is fundamentally and ineliminably contextual, and explicatae can only be assessed if there is more to their use, to their syntactic structure and to their intensional content than what is explicitly formulated in any stated explicatum (or linguistic framework). Such assessment involves, Carnap observes, matters of degree and some form of expected utility. There can be such expected utilities only if the context within which the explicatum is used has some sufficiently stable and identifiable structure unto itself such that some explicatae or some linguistic frameworks can be more effective or efficient than others, and can be noted - that is: judged - to be more effective or efficient than others. Carnapian explication requires and involves fundamental aspects of semantic, mental content and also justificatory externalism - the theses that some important aspects of semantic content (intension), of mental content or mutatis mutandis of cognitive justification are not expressly and explicitly formulated within the propositions or linguistic framework(s) in question, nor within or by the thoughts or judgments made by whomever devises, uses and assesses those explicatae. In sum, Carnap's (1950a, 1-18) own explication of the method of conceptual explication

of law and jurisprudence from future neuroscience. Those expectations are misplaced because the issues of identifying and justifying basic principles of justice are independent of neuro-physio-psychological explanations of how we are able to address these issues (Westphal 2016a). Quine preached 'naturalized epistemology' - a philosophical theory of knowledge which appeals to empirical psychology - though he never took his own advice (Westphal 2015). In principle and in practice, explaining how we can do $x$ can never suffices for justifying whether or when we ought (not) to do $x$. A philosophy of law remains incomplete unless it addresses fundamental issues about when a legal system deserves to be accepted as legitimate, per Weber’s $(1922, \$ 22)$ sociological definition of a political state, in contrast to a dominant protection agency (Nozick's term) - or worse. 
undercuts Carnap's (1950b) own best attempt to divide framework-internal from framework-external questions, and to escape issues about judgment altogether. (This is the root of objectivity to which Burge (2010) has sought to redirect philosophical attention.)

These points about the contextual character of judgment are undergirded by the 'open texture' of all empirical concepts (Waismann 1919, Austin 1920, Wittgenstein 1958), according to which in principle we cannot provide necessary and sufficient conditions for the proper use of any empirical concept, because future instances or observations may always reveal unexpected characteristics which require revising our concepts, our use of them, or both. (This is a key reason why there can be no pure procedural justice.)

These externalist aspects to conceptual explications and their development, use and assessment all involve judgment and judgments, the point and content of which cannot be reduced or restricted to the explicit contents (intension) of the propositions which may state the content(s) of the judgments, inferences, explicatae or linguistic frameworks involved.

Carnap's explication of conceptual explication also acknowledges that conceptual analysis, classically conceived as identifying the necessary and sufficient conditions for the proper use of any philosophically puzzling concept (term, principle, statement) is insufficient for substantive issues within philosophy of science. That is correct, though this observation holds for all non-formal domains. It is striking and significant that, like Carnap, Kant too distinguished methodologically between conceptual analysis and conceptual explication, in these terms, and made it central to his Critical method that we cannot presume to provide necessary and sufficient conditions specifying adequately the exact content (intension) of our key concepts and principles (KdrVA727-30/B755-8). Kant thereby dismissed Cartesian transparency about conceptual content, together with infallibilist presumptions about cognitive justification, indeed, about rational justification in all non-formal domains (morals and empirical knowledge).

A related reason why judgment is ineliminable was highlighted by Lewis Carol and by Quine. Carol (1895) pointed out that the inference principles used in syllogistic reasoning or proof cannot all be stated as explicit premises in that reasoning or proof, without launching an infinite vicious regress: any premiss - including any premiss stating a rule of inference - can only be linked to other premises by using a rule of inference which is not itself one of those statements. Similarly, Quine (1936) noted that specifying any formally defined logistic system - its basic symbols, terms and rules - requires using principles of deduction and also semantic rules in order to designate any set of marks as signs, to assign to those signs any semantic function, and 
to specify the formation and inference rules which are the specified logistic system. Using semantic rules and using rules of inference requires judgment: intentional, self-directed, self-assessing reasoning about whatever considerations pertain to the issue or inference or proof in question.

\section{Kant's Critical Reflections on Rational Justification.}

There is a pervasive if often implicit presumption that using rules is in principle no different than using algorithms to calculate by rote some desired conclusion as a corollary to whatever calculation one makes. This is false and deeply misleading. Even algorithms require judgment to develop them, to assess their adequacy and to assess their appropriate use. Rules or principles guide judgment; they do not dictate univocal, precise outcomes of judgment. The presumption that using rules or principles differs not at all from using algorithms, all of which is no more than the most mechanical use of syllogistic deduction has two sources, both highly influential within philosophy, though neither is philosophical.

One source was Étienne Tempier's condemnation in March 1277 of 220 neo-Aristotelian theses, mostly in natural philosophy, as heretical. Tempier's condemnation was issued upon authority of the Roman Pope as Bishop of Paris (Piché 1999, Boulter 2011). Both explicitly and implicitly Tempier's condemnation stated and implied that demonstrative knowledge requires proof that the opposite of the conclusion is impossible; all else is conjecture or opinion. This is where and how Aristotle's emphatically flexible, broadly Euclidian model of scientific knowledge was converted into deductivist infallibilism. Descartes' grappling with the possibility of a malignant omnipotent deceiver and his official view of scientific explanations as no more than 'possible' explanations of natural phenomena, all wait in the wings of Tempier's condemnation.

Much closer to our own day was the intensive effort during the Cold War to develop 'expert' systems of rules to try to safeguard against human error, which might lead to inadvertent or unwarranted though utterly disastrous nuclear strike. Systems of 'expert' rules can be very useful, though like algorithms, developing and assessing the use of expert systems of rules requires judgment. If as Russell once quipped 'there are only two forms of reasoning: deductive and bad', then there is only bad reasoning, because deduction alone cannot assess the appropriate use of the first premises of any deductive reasoning. Cold War fixation upon systems of deductive rules as solely constitutive of reasoning led reason very nearly to lose its mind (Erickson ef al 2013; cf. Porter 1995). Scrutinizing knowledge gained by deduction reveals how such knowledge involves much more than just deductive validity (Powers 1978). 
Central to Kant's critique of our human powers of judgment are four fundamental though insufficiently familiar points:

(1) Reasoning using rules or principles always requires judgment, to guide the proper application of the rule or principle to the case(s) at hand ( $K d r V$ B169-75). Specifying rules of application cannot avoid this, because using rules of application also requires judgment. Wittgenstein's alleged 'scepticism' about rule-following is not at all sceptical about rule-following: he was, after all, an architect. Wittgenstein was sceptical only about formalist views of rule-following, which treat the use of rules as mere algorithms - the view embedded in the formalism central to the 'expert' systems of rules sought in the Cold War. If philosophers would pay more and better attention to engineering and to actual natural sciences, rather than to pure mathematics or logical axiomatics, they would much better appreciate the use of rules in making or measuring approximations - however exacting those approximations may be. Such examples all confirm Kant's and Carnap's pronounced emphasis upon conceptual explication rather than conceptual analysis.

(2) Rational judgment is inherently normative, insofar as it contrasts to merely responding to circumstances by forming or revising beliefs, because judgment involves considering whether, how or to what extent the considerations one now draws together in forming and considering a specific judgment (conclusion) are integrated as they ought to be integrated to form a cogent, justifiable judgment (KdrV A261-3/B317-9, B219).

(3) Rational judgment is in these same regards inherently self-critical: judging some circumstance(s) or consideration(s) involves and requires assessing whether or how well one assesses (and judges) those circumstances or considerations as they ought best be assessed (KdrV A261-3/B317-9, B219).

(4) Rational judgment is inherently social and communicable (KdrV A8202/B848-50, A751-2/B779-80; KdU \$40), insofar as judging some circumstances or considerations rationally involves acknowledging the distinction in principle between merely convincing oneself that one has judged properly, and actually judging properly by properly assessing the matter(s) at hand. Recognising one's own fallibility, one's own potentially incomplete information or analysis and one's own theoretical or practical predilections requires that we each check our own judgments, first, by determining as well as we can whether the grounds and considerations integrated in any judgment we pass are such that they can be communicated to all others, who can assess our grounds and judgment, so as also to find them adequate; and second, by actually communicating our judgments and considerations to others and seeking and considering their assessment of our judgments and considerations (GS 8:145-6; below $\$ \$ 6.2,7.1$ ). 


\section{Hegel's Critical Reflections on the Possibility of Constructive Self-Criticism.}

6.1 Hegel recognised that the Pyrrhonian Dilemma of the Criterion is exposed as a mere sceptical trope by the exercise of critical self-assessment, by which we can re-assess each consideration in any stretch of justificatory reasoning, we can re-assess each use of each consideration within that reasoning, and we can re-assess each link between any pair (or plurality) of considerations. Fundamental to the possibility of constructive self-assessment, Hegel recognised, is that our awareness of any particular (object, event, structure, person, configuration, state of affairs, phenomenon) is not limited to the intensional (classificatory) content of whatever concepts, principles or propositions we bring to bear in judging that particular. Philosophers occasionally mention how important is self-criticism; Hegel is the only philosopher to analyse - indeed incisively - how it is possible, and how our capacity for

590 self-assessment solves the Pyrrhonian Dilemma of the Criterion (Westphal 2017, \$\$60-64, 83-91).

6.2 Hegel further argued that our individual capacity for critical self-assessment is both facilitated and augmented socially, by our collective capacities for constructive mutual criticism. Hegel's analysis of this point builds upon Kant's point about freedom of thought in 'What is it to Orient Oneself in Thinking?' There Kant contends that

... freedom in thinking signifies the subjection of reason to no laws except those which it gives itself; and its opposite is the maxim of a LAWLESS USE of reason (in order, as genius supposes, to see further than one can under the limitation of laws). (GS 8:145) ${ }^{7}$

This lawless use of reason naturally leads, Kant contends, to this situation:

... if reason will not subject itself to the laws it gives itself, it must bow beneath the yoke of laws given by another; for without any law, nothing - not even nonsense - can play its game for long. Thus the unavoidable consequence of declared lawlessness in thinking (of a liberation from the limitations of reason) is that the freedom to think will ultimately be forfeited, and because ... arrogance is to blame, it will properly speaking be foolishly trifled away. (GS 8:145)

Lawful, that is: regular, rule-governed use of reason is required simply to make sense; to make statements, claims, or judgments; to refer intelligibly and intelligently to any subject matter under discussion; to make any justified or justifiable claims or judgments; and to assess their accuracy and justification. These points likewise hold for innovations, their identifiability

7 Kant's Sperrdruck is rendered by small capitals. 
(recognisability), their rational assessment and, in favourable cases, their justification.

Lawlessness in reasoning generates instead:

... an unbelief of reason, a precarious state of the human mind, which first takes from moral laws all their force as incentives to the heart, and over time all their authority, and occasions the way of thinking one calls LIBERTINISM, i.e. the principle of recognising no duty at all. (GS 8:146)

These are exactly Hegel's points in 'The Animal Kingdom of the Spirit' in the 1807 Phenomenology (GW 9:216-28/\$\$397-417), where Hegel critically examines the interactions between a group of self-obsessed Romantic geniuses, each of whom proclaims that he alone understands and expresses whatever is of utmost importance to all. The direct consequence of this attitude is that anyone else's expressions are handled as nothing but raw materials for one's own - with the further result that no one understands or expresses anything at all intelligible. Hegel's 'Animal Kingdom of the Spirit' is decidedly a literary counterpart to Hobbes' lawless state of nature (cf. Shklar.1976, 96-141), a counterpart suggested by Kant's own discussion of this point, with express reference by name to Hobbes (KdrV A751-2/B779-80).

6.3 The positive successor to 'the Animal Kingdom of the Spirit' is achieved at the very end of 'Evil and its Forgiveness', the closing sub-section of 'Spirit' (GW 9:340-62/\$\$632-671). There Hegel draws the ultimate conclusions of his analysis of mutual recognition and its constitutive role in individual rational self-consciousness.

The central significance of Hegel's account of mutual recognition (Anerkennung) for rational justification is this: For anyone accurately and rationally to judge that $\mathrm{s} / \mathrm{he}$ is a rational judge requires (1) recognising one's own rational fallibility, (2) judging that others are likewise genuine, competent, yet fallible rational judges, (3) that we are equally capable of and responsible for assessing rationally our own and each other's judgments and (4) that we require each other's assessment of our own judgments in order to scrutinise and thereby maximally to refine and to justify rationally our own judgments. Unless we recognise our critical interdependence as fallible rational judges, we cannot judge fully rationally, because unless we acknowledge and affirm our judgmental interdependence, we will seriously misunderstand, misuse and over-estimate our own individual rational, though fallible and finite powers of judgment. Hence recognising our own fallibility and our mutual interdependence as rational judges is a key constitutive factor in our being fully rational, autonomous judges. Only by recognising our judgmental interdependence can we each link our human fallibility and limited knowledge constructively to our equally human corrigibility, our ability to learn 
- especially from constructive criticism. Therefore, fully rational justification requires us to seek out and actively engage with the critical assessments of others (Westphal 2017, \$\$60-64, 83-91; see below, \$7.6). ${ }^{8}$

According to Kant's and to Hegel's pragmatic fallibilism about rational justification, a judgment is justified insofar and so long as: (1) It is more adequate to its tasks than any alternative statement; (2) it is adequate to its designated range of use or phenomena; and (3) it remains adequate to its designated range of use or phenomena as its use is renewed upon new, relevant occasions, which may included changed circumstances, context or information. In this way, Hegel further argues, the social and historical dimensions of rational justification in all non-formal domains requires and justifies realism about the objects of empirical knowledge and also strict objectivity about fundamental moral norms.

6.4 The contrast I have mentioned between formal and non-formal domains is very specific: the one purely formal domain is a precise re-statement of Aristotle's square of logical oppositions, within which form alone suffices for the logical validity of these oppositions, which specify 'all, 'none', 'some', 'some not' and 'not' (cf. Wolff 2009). All further domains - including mathematics and all other formalised domains - require semantic and existence postulates which are not themselves purely formal. Deduction suffices for justification within purely formal domains because deduction constitutes justification within purely formal domains. However, because non-formal domains involve non-formal semantic and existence postulates, deduction alone does not constitute justification within non-formal domains. 'Fallibilism' regarding justification is the view that justification sufficient for knowledge does not entail the truth of what is known. Fallibilism about justification is entirely compatible with our knowing necessary truths, say, in mathematics - or also in transcendental philosophy about, e.g., necessary features of rational human judgment. The 'fallibility' of the justification of any claim does not require that the claim might be false; it allows that any claim or its justification may be revisited and perhaps revised - though revisions may make it more precise, or its justification may be further corroborated or strengthened! That there is no finality to rational justification in non-formal domains, does not entail that we err, nor that we lack sufficient accuracy or justification.

8 Conversely, constructive mutual criticism is undermined by piecemeal, unsystematic philosophy, by philosophical factionalism ('cultural circles' or 'philosophical stances' in van Fraassen's [2002] sense), by substituting philosophical lines of policy for philosophical theses (Carnap 1950b [1956, 208], cf. Wick 1951), by neglecting Carnap's (1950b, 1-18) distinction between conceptual analysis and conceptual explication or by neglecting the distinction between formal and non-formal domains; see Westphal (2015c; 2017, $\$ \$ 100-110)$. 
Kant's four cardinal points about the normativity of rational judgment (above, $\$ 5$ ) are non-formal truths; nevertheless, they are truths about our capacity to form, justify and assess rational judgments. Such judgments and our exercising such judgment are required for us to make sense, to make any claims and to justify our claims - whether regarding facts, norms or acts. If those four cardinal points may be revisited or revised, any revisions will take the form of improving precision (and I have stated only the minimum necessary; Kant's precise statement is his entire critique of judgment throughout his Critical corpus) or corroborating their justification (or both). This is because any revisions must use these same normatively structured functions of rational judgment (see below, \$7.4). ${ }^{9}$

\section{Freedom and the Right to Autonomous Judgment.}

If these issues about judgment, rational justification and fallibilism may seem far removed from issues of human rights, they are not - quite the contrary. Consider first how Kant linked them, for here too Hegel built upon and further built up Kant's Critical account of our capacities to judge.

7.1 Kant concludes 'What is it to Orient Oneself in Thinking?' emphatically:

Friends of the human race and of what is most sacred to it! Accept what appears to you most worthy of belief after careful and sincere examination, whether of facts or rational grounds; only do not dispute that prerogative of reason which makes it the highest good on earth, the prerogative of being the ultimate touchstone of truth. ${ }^{*}$ Otherwise you shall become unworthy of this freedom, and you will surely forfeit it too; and besides that you will bring the same misfortune down upon the heads of other, innocent parties who would otherwise have been well disposed and would have used their freedom lawfully and hence in a way which is conducive to what is best for the world! (GS 8:146-7; tr. Wood)

9 Kant's four points about rational judgment are synthetic claims which can be known a priori. Rejection of 'the' synthetic a priori because (supposedly) it involves or allows intuition of metaphysical truths is non-sense rooted in empiricist presumptions about 'rationalism'. Kant undermined rationalist metaphysics by appeal to a basic cognitive-semantic point he learned from Tetens, who held that to 'realise' a concept is to demonstrate - ostend, point out, provide - instances to which that concept properly applies. This requires, Kant argued - cogently - localising relevant particular instances within space and time. In this way, Kant secured the key aim of verification empiricism, without invoking verification empiricism! Kant's cognitive-semantic point holds regardless of the concepts or propositions (intension) at issue (Westphal 2004, 2013b). Hegel argued independently and cogently for this same basic cognitive-semantic point in the first chapter of the 1807 Phenomenology of Spirit (Westphal 2000, 2002-03, 2010). Hegel further realised that this cognitive-semantic point suffices to reconstruct the entirety of Kant's critique of judgment, without appeal to transcendental idealism - nor to any comparable view (Westphal 2017). 
Now why, exactly, should reason be the ultimate touchstone of truth? Kant answers in his footnote to his conclusion:

*Thinking for oneself means seeking the supreme touchstone of truth in oneself (i.e. in one's own reason); and the maxim of always thinking for oneself is ENLIGHTENMENT... . To make use of one's own reason means no more than to ask oneself, whenever one is supposed to assume something, whether one could find it feasible to make the ground or the rule on which one assumes it into a universal principle for the use of reason. This test is one that everyone can apply to himself; and with this examination he will see superstition and enthusiasm disappear, even if he falls far short of having the information to refute them on objective grounds. (GS 8:146-7n; tr. Wood)

The 'enthusiasm' Kant here censures is the view that reason's legislation is invalid, whereas 'superstition' is 'is the complete subjection of reason to facts', 594 whether real or alleged (GS 8:145). A 'universal principle for the use of reason' is a principle any and everyone can use to judge some subject matter. This reflects Kant's observation in the Canon of Pure Reason, that 'all knowledge (if it pertains to an object of pure reason) can be communicated' ( $K d r V$ A829/B857). This communicability of knowledge does not merely consist in announcing one's opinions to others; it consists in publicising one's analysis, justificatory grounds and concluding judgment to others so that they too can consider one's analysis, grounds and judgment, so that they too can find it cogent and sufficiently justified ( $K d r V$ A822-3/B850-1). This possibility of communicating one's knowledge is a necessary condition constitutive of knowledge of any and every public object, event, structure, phenomenon, principle or practice. The Critical question Kant poses for any- and everyone's use of reason in this footnote is an important step forward from Kant's Transcendental Doctrine of Method to the universalisability tests first presented in the Groundwork of the Metaphysics of Morals.

7.2 The key to Kant's universalisability tests is that universal communicability (of this kind) is a necessary condition for rational justification in all non-formal domains. Consequently, any claim or principle - together with its purportedly sufficient justifying reasons - which cannot be universally communicated cannot, accordingly, be rationally justified. This holds independently of the character, content or apparently compelling character of the claims, principles or reasons at issue. Kant's insight into the moral assessment or justification of actions is this: No omission of strict moral duties, and no commission of morally prohibited actions, can be justified to all others by communicating the principles and purported justifying reasons for so acting (or omitting to act), such that they too can upon consideration assess one's proposed action and its purported justifying grounds, and can decide and act on those same considerations on the same occasion and in 
the same way as one thinks or acts. Maxims and acts of exploitation, illicit coercion or strong-armed robbery are ruled out because they over-power at least one person's powers to decide how to act upon sufficient justifying grounds; maxims and acts of deception, fraud, lying or other forms of illicit stealth are ruled out because they evade at least one person's powers to decide how to act upon sufficient justifying grounds. No such act can be justified by sufficient reasons addressable to all others, such that they too can consider, think, decide and act on those same grounds and in that same way, on that same occasion and on all such occasions. ${ }^{10}$

Because universal communicability of principles and their (purported) justifying grounds is a conditio sine qua non for the rational justification of those principles, together with any thought or action based upon or guided by them, Kant's Natural Law Constructivism (Westphal 2016a) circumvents or at least circumscribes debates about 'values', especially when used as premises in moral assessments or justificatory moral reasoning. Of course there are important issues to be settled jointly - whether locally, domestically or internationally - about values, aspirations, policies, legislation and their often competing recommendations, but those debates can only occur, can only be effective and can only be resolved for cogent reasons, within the scope of the strict duties of justice identified by Kant's universalisation tests, independently of such contingent and diverse material premises. Consequently, moral or political debates about 'values', aims and aspirations can only pertain to elective, in principle justifiable policies, procedures, laws, customs or conventions. Debate about 'values', aims and aspirations as material premises in moral reasoning does not pertain to the most fundamental principles of justice, which are the most fundamental principles of morals, identified and justified by Kant's Natural Law Constructivism.

7.3 Freedom of thought, communication and action are all constitutively linked to freedom of rational judgment. Because we are free to do or forebear, we can act as we should not. Hence moral prescriptions are for us imperatives: permissions, prohibitions or obligations. Because we cannot create anything ex nihilo, we cannot act at all without using space, time and materials around us. Because we are so interdependent, using materials effectively hence without hindrance by others - requires social coördination by acting according to publicly established and acknowledged principles and practices, so that we may each know how not to interfere with others' use of their possessions. We are each within the moral domain because there is so very much we can and ought - or ought not - do to respect, assist, minister to or restrain others' needs or actions. Because rational judgment is normatively

10 Kant's universalisability tests eliminates logoi which cannot possibly be orthoi; see Westphal (2016f). 
structured (per $\$ 5$ ), it can be neither fully explicated nor explained in strictly causal terms (Westphal 2016e, h). Freedom of action involves judging and deciding how to act. This requires exercising instrumental reasoning about which ends, strategies and means are feasible within the limits of one's currently available resources, skills and abilities. Freedom of action also requires judging and deciding how it is permissible to act, or which act is (or which acts are) impermissible to omit. Judging what is and is not (im)permissible requires using Kant's universalisation tests. Only by using these tests can we solve basic problems of social coördination legitimately, by solving them on the basis of reasons and analysis which are universally communicable (in the sense specified above, $\$ 5$ ), and hence abide by Rousseau’s independence requirement, which is Kant's sole innate right to freedom. No norm can be justified merely by empirical evidence, nor by mere logical or conceptual analysis. Normative justification lies in our rational capacities to judge and to act responsibly by achieving our ends only in ways which can be justified to all others, in part by honouring the host of acquired rights and obligations we very finite, mutually interdependent, embodied semi-rational agents inevitably require and acquire by living in a polity and its economy here on Earth. Amongst the facts to which reason in one's own person should not be subordinated - to do so would be, as Kant says, superstitious - are facts about one's own desires, preferences or inclinations, or also facts about one's belonging to one or another tradition or community. Only by reasoning cogently and publically in view of Kant's Critical analysis of our rational powers of judgment, together with his (merely implicit, never explicated) 'practical anthropology' - an inventory of basic constitutive features of our finite embodied agency: what we homo sapiens semi-sapiens ARE capable of doing and suffering, not what(ever) we may happen to believe or to feel or to admit we can do or suffer - can we identify and justify the most basic principles and practices of morals. These basics suffice to secure peace and sufficient concord for us legitimately to pursue, assess or plan our common wealth, domestically and internationally. Only because we are free rational beings are we within the moral domain; only because we can rationally understand, examine, address and (provisionally) resolve these issues about how best to act within the limits of justice and moral responsibility are we morally imputable agents - regardless of whether we recognise and fulfill our obligations. Rather than restricting justification to whatever grounds can motivate agents - an internalist and empiricist strategy - Kant's Natural Law Constructivism first identifies and justifies what our duties and obligations are; the issue of bringing human motivation into accord with obligation Kant assigns to education - in all its forms - and to philosophy of education, all guided by the rights and obligations identified and justified by Natural Law Constructivism. All of these point are equally fundamental to Hegel's further developments and justification of Natural Law Constructivism. 
7.4 When lecturing upon $\$ 433$ of his Philosophical Encyclopaedia, concerning the defective form of mutual recognition of master and bondsman, $\mathrm{He}-$ gel observed:

... in this relation [of master and bondsman,] the posited identity of self-consciousness of those mutually related subjects [has] only been established in a one-sided way.

As concerns the historical aspect of this relation now under discussion, it may be remarked here, that ancient peoples, the Greeks and Romans, had not yet achieved the concept of absolute freedom, as they didn't know that the human being as such, as this universal I, as rational self-consciousness, is entitled to freedom. Amongst them, the human being was instead only held to be free, if he was born free. Hence amongst them freedom still had the characteristic of naturality. Hence in their free states there was slavery and amongst the Romans there were bloody wars in which slaves sought to free themselves, and to win recognition of their eternal human rights. (Enz. \$433Z; tr. KRW)

Important here is Hegel's characterisation of the very concept of 'absolute freedom', as the right to freedom of any human being as such. This is indeed the crucial constitutive universalisation of freedom as a right of human beings, and so of each and every human being as such (universal rights), in contrast to juridically granted communal or political rights to freedom (rights of membership). ${ }^{11}$ To be sure, Hegel reiterates this key point, that "justice (Recht) and all of its determinations are grounded solely upon free personality, a self-determination', in his published Remark to Enz. \$502. ${ }^{12}$

This absolute concept of freedom and of the individual right to freedom $\mathrm{He}-$ gel discusses in his Philosophical Outlines of Justice when contrasting property,

11 Hegel's discussion here of the 'absolute concept of freedom' is quite the opposite to the 'absolute freedom' which all too easily leads to political terror (PhdG, GW 9:316$28 / \$ \$ 582-595)$; that 'absolute freedom' is the negative freedom of individuals from their economic, civil, political and juridical principles, institutions and practices.

12 Because scepticism about Hegel's views is so entrenched, here is his Remark in full: "The expression natural law (Naturrecht), which has typically denoted philosophical doctrine of justice, contains the ambiguity, whether justice (Recht) is something immediately on hand naturally, or whether it is meant as specified by the very nature, i.e. by the concept [of justice]. Previously the former sense was typical, so that at once a state of nature is feigned, in which natural justice is supposed to be valid, whereas the social condition and the state is rather a limitation of freedom and requires sacrificing natural rights. In fact, however, justice and all of its determinations are grounded solely upon free personality, a self-determination, which is rather the opposite of a natural determination. Hence natural justice is the existence of strength and force making itself valid, and a state of nature is a condition of violence and injustice, about which nothing can be more truly said, than that it shall be vacated. In contrast, society is instead the condition in which alone justice has its actuality; what is to be limited and sacrificed is indeed the arbitrariness and violence of the state of nature' (Enz. \$502R; tr. KRW). 
which in principle is always alienable, to inalienable, entirely personal goods. Here is the relevant passage, translated from Hoymeyer's transcript of Hegel's lectures of 1818-19:

$\$ 35$ [Alienation of property and its limits] My property I can alienate, insofar as by its nature the thing is something external. Accordingly, those goods are inalienable - just as the right to them cannot expire - which constitute my own-most person and the universal [character] of my self-consciousness, - as my personality as such, freedom of the will, ethical life, religion.

If inalienable goods nevertheless are alienated, their restoration can thus be demanded immediately, for they are without term: Droits de l'homme.

One must not remain with this abstraction of these human rights. Yet this principle as such is absolute [sic]: that, even if a nation has alienated these rights, they can immediately reclaim them.

My ethical law is my being; it is not something alien to me. In religion I intuit my being, I seek to produce within myself the consciousness of my identity with my being. How can it occur, that these be alienated, that another becomes master of our ethical life etc.? The reason is that such relations consist in my making myself objective within them, that I posit a differentiation between myself as particular and as universal; if I remain merely particular, then the universal is for me a power, something foreign, an external power. [This is] the path of superstition, servitude. Hence I must know the universal in stable identity and relation to me, to remain truthfully extant. The slave, so soon as he says he is free, is from that moment free and owes no compensation to his master, indeed he can still demand provisions from him. Thus one can liberate oneself also from any coercion by ethical life or by religious faith. (Nachschrift Homeyer, Berlin 1818-19; Ilting 1985, 230; tr. KRW)

Hegel stresses exactly this contrast - between that which in principle may be alienated and our inalienable, most personal rights and freedom to live ethically and piously in understanding ourselves and our moral obligations and aspiration - in all of his lectures, in his own lecture notes, and in the published text of Rph $\$ 66$ and his Remark to that section. ${ }^{13}$

In exactly this same connection, Hegel stressed at the outset - against the historical school of jurisprudence (Hugo, von Savigny) - that for all their juridical accomplishments, the Romans lacked a proper definition of the human being as constitutively free $(R p h \$ 2 \mathrm{R})$; only thus could they admit slavery $(R p h \$ 3 R)$, though consequently neither the Romans, nor their fervent

13 Cf. Rph $\$ \$ 65,66+\mathrm{R}(G W 14.1: 29 ; 14.3: 78,15)$; Vorlesungen zur Rechtsphilosophie: $1817-18$, $\$ 29 ; 1818-19$, $\$ 35$ : Ilting 1:263-4; 1819-20, 29.470-494; 1822-23, re: Rph $\$ 66$, Ilting 2:273, 3:249, 255; 1824-25, re: $R p h \$ 57+\mathrm{R}$, Ilting 4:241-2; re: Rph $\$ 66 \mathrm{R}$, Ilting 2:277; re: Rph $\$ 68 \mathrm{R}$, Ilting 4:239. 
conservative advocates, the historical jurisprudes, could grasp the proper basis of justice and rights, which is the free human will, our rational capacity to judge and decide how to act (Rph $\$ 4)$.

7.5 Equally important to the absolute right to freedom of each and every human being, is Hegel's observation that 'One must not remain with this abstraction of these human rights'. Instead, Hegel's Outlines detail why each and every human being in an industrialised commercial nation deserves citizenship in a sufficiently just, well-functioning (small ' $r$ '!) republic. To be legitimate, a republic must establish, secure, facilitate and promote fundamental civic rights and freedoms of person, belief, property, profession and trade (Rph $\$ \$ 35,36,38,41-49,57,62 \mathrm{R}, 66,206,207,209 \mathrm{R}, 252,270 \mathrm{R}$ ), including the rights to earn one's livelihood, to effective political representation and to being regarded as an equal citizen in good standing (Rph $\$ 241,244, c f$. $\$ \$ 238 Z, 244 Z$ ). Acquiring and exercising such rights further requires honouring each newborn's right to proper and sufficient nurture and education, both informal and formal (Rph $\$ \$ 174,209+\mathrm{R})$. Education must centrally include education for that most important public office - the office of citizen.

Hegel's Philosophical Outlines of Justice details how to instantiate and institutionalise human rights by integrating them with correlative human responsibilities and opportunities within republican commercial societies, where the absolute right to freedom is and remains the fundamental benchmark for the legitimacy of our political, civil and legal institutions and practices, all of which are to protect, promote and respect the development and exercise of mature judgment in all of our deliberations and activities, whether familial, social, civil or political. The absolute concept of individual freedom must continually be reconsidered as we come to reconfigure our freedom by reconfiguring our free activities through our on-going cultural, economic, civic and political developments. Hegel's institutional designs for legislation and for political representation aim to monitor the actual workings and consequences of our activities, individually and collectively, with regard to the sociological law of unintended consequences, so that social practices required for legitimate free individual action be preserved or whenever need be protected legally, to counter-act unintended consequences of social practices which jeopardize individual freedom of action, and to revise legal and civil institutions so as to avoid or to minimize so far as possible such illegitimate, unjustifiable unintended consequences of social practices - including, centrally, economic, financial, legislative and political practices (Westphal 2016c, d).

The plurality of culturally, historically or legally specific conceptions of human rights is not, of itself, a problem, nor should it be surprising: We should expect the identification and formulation of human rights and obligations 
to keep pace with new developments in the ways and means of degrading, evading, exploiting or violating the freedoms, responsibilities and vulnerabilities of individuals' finite embodied semi-rational agency ( $c f$. Beyleveld \& Pattinson 2000, 2010). My point here is, with Hegel and Kant, to identify the fundamental principle which justifies human rights as such, because it protects and promotes the very same rational freedom and capacities to identify and to justify basic moral principles as such, which hold for all of us finite, embodied semi-rational human agents. In this regard, we can agree with jurists who rescind natural law theory because an invariant yet specific, action-guiding law for all human cultures for all times is not to be found, without succumbing to historicism - nor to positivism - because the fundamental principles and processes of rational justification (in non-formal domains), together with their constitutive roles in free and responsible rational action, are constant: they are constitutive of the 'absolute concept of freedom' Hegel identifies, which serves as a guide to understanding and assessing how and how well current social practices - including the economy as well as government, communications and social and civil institutions - serve to support, protect and foster free responsible action by each and everyone, or to identify regards in which current social practices and institutions require and afford improvements in achieving and sustaining freedom and justice for all.

This is the insight Hegel learnt from Montesquieu $(R p h \S 3+\mathrm{R})$ : None of us can by ourselves devise an adequate scheme for securing human freedom and justice; instead we must examine actual human activities as they have developed and are practised today, and as we engage in them as we anticipate and plan for tomorrow. This is one reason why history is so central to Hegel's philosophy, including the history of Roman law and its Modern Occidental offspring. Moral philosophy, too, must be conducted as we have only too recently learned that history and philosophy of science must be conducted, wherein actual science - or actual human activities - must be accounted for properly and in detail by credible philosophical principles and theories. Empirical information never suffices to identify or to justify normative principles or practices, though detailed empirical information about how we free, semi-rational agents have figured out how to achieve our ends effectively is indispensable to normative theory, and to improving the legitimacy and effectiveness of our normatively structured practices, which always involves their on-going assessment, if we but pay attention to our manifold opportunities for constructive self-critical assessment and for mutual critical assessment. Self-styled radicals - whether right- or left-wing - who dismiss the adequacy or relevance of contemporaneous legal, political and economic structures are not nearly radical enough, for they fail to recognise how our freedom of action and our rational capacities and abilities to assess the adequacy and 
legitimacy of social practices and institutions are deeply rooted in our shared practices. ${ }^{14}$ These fundamental features of human agency and moral normativity can and should be made much more central to education for citizenship.

7.6 Education for citizenship involves not only considerable content regarding public institutions, principles, opportunities and procedures, it also involves these key skills and abilities, constitutive of mature judgment: (1) to discern and define the basic parameters of a problem; (2) to distinguish relevant from irrelevant and more relevant from less relevant considerations bearing on a problem; (3) to recognize and to formulate important questions and sub-questions which must be answered in order to resolve a problem; (4) to determine proper lines of inquiry to answer those questions; (5) to identify historical or social factors which lead people - including ourselves! - to formulate questions or answers in particular ways; (6) to think critically about the formulation or reformulation of the issues; (7) to consider carefully the evidence or arguments for and against proposed solutions; (8) to accommodate as well as possible the competing considerations bearing on the issue; (9) through these reflections and inquiries, to resolve a problem, so far and so well as is now possible; and ultimately (10) to organize and to present these considerations clearly and comprehensively to all interested - that is, to all affected - parties (Westphal 2012, 2016e). (Note that accommodating competing considerations requires assessing which of these considerations are legitimate, insofar as they are consistent with the independence requirement.)

Because rational justification in all non-formal, substantive domains is fallible, to judge rationally is to judge matters thus:

To the best of my present abilities, understanding and information, this conclusion is justified for the following reasons and in the following regards - what do you think?

This point of humility about the fallibility of one's own rational competence follows from and supplements the four basic points regarding rational judgment and justification indicated earlier (\$5).

Because rational judgment is fallible, and because it involves one's own, as it were, 'perspectival' assessment of the relevant evidence, principles and the interrelations among these, rational judgment is also fundamentally social. Constructive mutual criticism facilitates constructive self-criticism and renders it a social phenomenon by facilitating (or enabling) the identification of discrepancies between our conceptions of our knowledge and the objects of our knowledge and our experience of the objects we know and

14 In this I agree with Dewey, F.L. Will (1988) and James Wallace (2008), each of whom followed Hegel's lead in this important regard. 
our experience of our own cognitive constitution and activities, and analogously for action, regarding either intended and actual consequences or purported and actual justifying reasons. 'Reason' and 'rationality' are exhibited, not primarily by deductive competence, but by responsiveness to evidence, analysis, reasons and their assessment, in ways which can and do improve our views, whether by corroboration, elaboration, revision or rejection. Deductive logic is, as Kant (KdrV A10-12, 53, 60-3, 797-8/B24-6, $77,85-8,824-5)$ recognised, a canon for judgment, but outside pure axiomatics, deductive logic is no organon for knowledge, neither in morals nor in empirical knowledge. Acquiring, assessing and improving our knowledge and understanding requires recognising our own fallibility, and our capacity for self-critical assessment, and our constitutive interdependence, first to become rationally competent, imputable agents, and second to re-assess our own most considered judgments ( $c f$. Westphal 2016f). Rationality requires modesty and humility about our own most considered judgments. This is consistent with our advocating our views vigorously, but rules out our advocating or applying them dogmatically, and especially not to the disadvantage of others' legitimate interests.

7.7 To devote this much attention to details about judgment and rational justification in order to justify and to highlight the importance of modesty or humility may seem absurdly anti-climatic. To the contrary, precisely this constitutive role for humility and modesty in rational judgment and justification is decisive for the ecumenical universalism we most dearly need in matters moral, and it is decisive for distinguishing credible views worth considering, and worthy interlocutors who represent those views sincerely, from the welter of forms of domineering egoism, extremism, power-mongering, sociopathic dogmatism, narrow-mindedness or sheer idiocy - the kinds of dogmatism which insist that one's own size does fit and must be fitted to all others, regardless of what they may justifiably say or think about it.

This humility, modesty and inquiring reconsideration of core issues and our most considered judgments on those issues is a fundamental, ecumenical, very widely and centrally shared tenet of credible moral views globally and historically; it is central to Taoism, Confucianism, Buddhism, Shinto, Ancient Greek moral philosophies, all three Abrahamic religions - Judaism, Christianity and Islam (cf. Runzo \& al. 2003) - and to secular humanism; e.g., the Ethical Culture Society. These three virtues are the moral and jurisprudential counterparts to the Hippocratic oath: Above all, do no harm! These three virtues are (partly) constitutive of moral integrity, which is required both to acquire and exercise rights and to hold and execute obligations (Westphal 2016f). These basic points are (partly) constitutive of our being trustworthy, and so to our being responsible members of the moral community. 
One reason why this humility and modesty are so important lies in an important observation by Kant, which Hegel recognised and augmented: They both adopt, endorse and justify an important Stoic aspect of individual rational freedom - the freedom to neglect one's own desires or inclinations because they are judged to be unworthy, illegitimate or immoral. The root of 'radical evil' in human nature is our chronic tendency to grant priority to whatever one desires over what morality requires, rather than granting priority to what morality requires over whatever one desires. Yes: merely instrumental accounts of rationality are radically evil, as are self-aggrandizing neo-liberal claims to profits over civil and human rights of all citizens. As noted above, Kant and Hegel identify superstition with subordinating one's own reason to facts - of whatever kind. These facts may include, e.g., one's de facto inclinations, preferences or expected utilities, or instead one's communal tradition. Like all forms of superstition, i.e., all forms of subordinating reason to facts, these views too are heteronomous. That one happens to want something, or that one proposes to act in accord with one's traditions, does not, of itself, touch the moral questions of whether what one wants or proposes may be prohibited, permissible or obligatory. ${ }^{15}$

\section{Distinguishing Criticism from Cavil, Prophecy from Pretext.}

Doubtless some will respond to these considerations about rational judgment and justification as I did to Pettit's appeal to psychology, but such rejoinders are mistaken, profoundly so. Kant's four cardinal points about the normative structure of judgment (above, \$5) are altogether neutral about normal human psychology as any substantive basis for understanding mental health and its social conditions. More likely are rejoinders which press those four points into the place held by a major premiss in a simple deductive syllogism, and then reject that premiss modus tolens tolendo. Such rejoinders are, in principle and in practice, unalloyed examples of ancient scepticism: they insist dogmatically that dogmatism is the only possible form of rational justification. This is false in theory and pernicious in practice, regardless of how widely shared such practices and attitudes may be. These features of rational judgment and the explication of mature judgment (above, \$7.6) help to identify genuine cases of critical assessment, and to distinguish these from mere

15 The most sophisticated form of merely instrumental justification of moral principles is Gauthier's contractarianism; I respond to it en detail - and on Kant's behalf - in Westphal (2016a), \$\$29-34. Kant's 'Incorporation Thesis' (Allison's designation), that no desire, inclination, ground or principle is a motive to act unless and until it is incorporated by the agent into her or his judgment about how to act - simply applies Kant's theory of judgment to action; Hegel adopts the same view $(R p h \$ \$ 5-7 f f)$. Issues about causal determinism and freedom of the will are fundamentally ill-conceived, and require no idealist solution: In principle the key premiss of the debate is unjustifiable; see Westphal (2016g). 
rejoinder, protest or rejection. Of course someone might say that the present analysis is just one more Occidental view seeking to impose itself upon others - but talk is cheap: justifying any such assessment requires detailed analysis and evidence, quite the opposite of mere cavil.

To the rejoinder that I stake my account of freedom, rights and duties on a specific and controversial kind of epistemology, I grant that I do so, and I respectfully submit that I have examined the relevant epistemological issues and views in sufficient critical detail over the past three decades. I further submit that the present considerations about rational judgment, justification and their social dimensions provide much stronger justification for the republican rights to non-domination and to justification than those provided by Pettit, Honneth or Forst. ${ }^{16}$ If someone proposes another way to identify and to justify basic moral norms, let him or her first show that the alternative approach does not succumb to the Pyrrhonian Dilemma of the Criterion (above, $\$ 3){ }^{17}$

To insist that only uncontroversial claims can serve as premises in justificatory arguments is, in Kant's phrase, the euthanasia - if not suicide - of reason: Controversy only merits respect when it is supported by cogent reasons and reasoning. This requires a kind and scope of education, training and consideration that has been - and continues to be - eroded and undermined by over-specialisation in the field, coupled with excesses of conventionalism unleashed by Quine and his followers (Westphal 2015). Excellent scholarship on Kant's Critical philosophy has been available in English for over a century (Watson 1891, Caird 1899), but 'mainstream' Anglophone philosophers continue to think in the pre-Critical ruts carved by Descartes, Hobbes, D'Holbach and Hume (cf. Westphal 2016g).

Turning to more practical issues, there can be no serious justificatory question that peace and petition have moral priority - as matters of justice, right and freedom - over petulance and perfidity. Identifying and distinguishing

16 Forst $(2007,2011)$ rightly stresses reciprocity and interdependence, but relies too much upon acceptance and consensus - or rather, does not examine the issues involved in distinguishing between de facto acceptance or consensus, and what principles, institutions, practices or policies merit acceptance, and so merit consensus as well. His view is internalist about justification, and suffers from the problems infecting coherentism and reflective equilibrium discussed above (\$3). A more robust account of reciprocity is provided by Becker (1986).

17 Here I have not solved the Pyrrhonian Dilemma; I have only indicated some main points, and cited other research in which I examine, reconstruct, assess and defend Hegel's solution to it (Westphal 2017). In my (2016a) I examine two paradigmatic alternatives: Gauthier's sophisticated contractarianism, and Hume's sentiment-based ethics, and argue in detail that neither these, nor the host of related contemporary forms of moral constructivism, succeed in identifying or justifying basic moral norms. 
actual instances of petulance or perfidity is not always easy, but one central indicator is the hallmark of rationality indicated above (\$7.6): responsiveness to relevant evidence and cogent analysis. I am under no illusions about the many ways and the vast extents to which political processes and discourses not only neglect, but trample, evade or subvert the conditions required to form and to act upon mature judgments, often aiming to impose self-interested, factional or immature judgments upon the processes of legislation. Rather than concede that such practices belie the irrelevance of these considerations about mature judgment, let me turn those tables by using the conditions for mature judgment to underscore just how far we have allowed many of our political and legal institutions to stray from legitimacy. In many jurisdictions - foremost amongst them perhaps is my own 'homeland' and its insecurities, imaginary or real (the USA) - we have developed systems of political representation which only respond to group needs or interests within the short to medium term, where the brevity of the term is set by election cycles ( $c f$. Truman 1951, Olson 1965), so that none remain who speaks on behalf of the commonwealth and its long-term interests in justice, infrastructure and basic social services, sustainability (cf. Jones 1975, Curren \& Metzger 2017) and sound fiscal policy and practice (Buchanan \& Wagner 1977).

There are splendid exceptions to such trends in the Nordic and Scandinavian countries, and to a significant extent also Germany. The decline of selfstyled liberal democracies into tyrannical majorities - or vocal minorities - can only be blocked by robust, inclusive, small 'r' republicanism. Some institutional provisions to counter such descent into competing political special interests are, e.g., the Italian law which requires all citizens to vote in national elections, and facilitates their voting by making election day a holiday; the ballot option of voting for 'none of the above' (NOTA), used in Bangladesh, Columbia, India, Greece, Spain, Ukraine, and in Russia - introduced by Gorbachev, though abolished in 2006 - though only in one state of the USA: Nevada. Perhaps most impressive was the provision of ancient Athenian democracy to protect democracy against demagoguery by public voting for ostracism, by which arrogant power-mongers could be sent abroad for a decade - in sharp contrast to current politics, when such arrogant types are most likely to be elected to high office. To that ancient Greek practice we owe the very term 'ostracism': votes were recorded by etching a candidate's name on pot sherds called 'ostraka' (singular: 'ostrakon').

\section{Conclusions.}

To the best of my present abilities, understanding and information, these conclusions about justice, rational justification and human rights are justified for the reasons and in the regards summarised herein; pray tell, what do 
you think - and why? How and how well does your assessment withstand this kind of critical scrutiny? Our lives, our laws, our systems of justice and the Socratic health of our souls hang in the balance. We can afford no further negligence in these decisive matters! ${ }^{18}$

\section{References}

Alston, William, 1989a. Epistemic Justification: Essays in Epistemology. Ithaca, NY, Cornell University Press.

Austin, J. L., 1946. 'Other Minds'. Proceedings of the Aristotelian Society, Supplementary Volume 20:173-187; rpt. in: idem. (1979), 76-116.

- - , 1979. J. O. Urmson, ed., Philosophical Papers, 3d ed. Oxford, The Clarendon Press. Becker, Lawrence, 1986. Reciprocity. London, Routledge \& Kegan Paul.

Bell, David, 1979. Frege's Theory of Judgment. Oxford, The Clarendon Press.

Berolzheimer, Fritz, 1912. The World's Legal Philosophies. Boston, Boston Book Co.

Beyleveld, Deryck, and Shaun Pattinson, 2000. 'Precautionary Reasoning as a Link to Moral Action'. In: M. Boylan, ed., Medical Ethics (Upper Saddle River, NJ, PrenticeHall), 39-53. 2010. 'Defending Moral Precaution as a Solution to the Problem of Other Minds: A Reply to Holm and Coggon'. Ratio Juris 23.2:258-273.

Bonjour, Laurence, 1997. 'Haack on Justification and Experience'. Synthese 112: 13-23.

Boulter, Stephen, 2011. 'The Mediaeval Origin of Conceivability Arguments'. Metaphilosophy 42.5:617- 641.

Brentano, Franz, 1874. Psychologie vom empirischen Standpunkt, 2 vols. Leipzig, Duncker und Humblot.

Buchanan, James, and Richard Wagner, 1977. Democracy in Deficit: The Political Legacy of Lord Keynes. New York, Academic Press; rpt. Indianapolis, IN: The Liberty Fund, 2000.

18 I am most grateful to Marcus Düwell for his very kind invitation to address his conference, 'The Future of Human Dignity', which he organised with joint sponsorship from the Universities of Utrecht, Erasmus (Rotterdam), Tilburg and Leiden, and The Netherlands Organization for Scientific Research (NWO) (11-13 Oct. Utrecht; http:// humandignity.sites.uu.nl/the-future-of-human-dignity/). Without Marcus' gracious, irresistible invitation I would have lacked temerity to wade into these fraught issues! Discussions there and questions from the audience were very stimulating and helpful, in particular from Deryck Beyleveld. Stanley Paulson, too, I thank for advice. Responsibility for errors, foolishness or truculence exhibited herein is solely my own; this too belongs to moral imputability. Further developments and helpful discussions were prompted by invitations to address two additional conferences: „Regelfolgen, Regelschaffen, Regeländern - die Herausforderung für Auto-Nomie und Universalismus durch Ludwig Wittgenstein, Martin Heidegger und Carl Schmitt", sponsored by the Seminar for Philosophy and the Juridical Faculty of the Martin-Luther-Universität Halle-Wittenberg (1-3 Nov. 2016); and 'Dealing Normatively with Deep Differences: Existing Approaches', sponsored by the British Academy Newton Advanced Fellowship Research Project, and the Forum for European Philosophy (Oxford), organised by Sorin Baiasu (Keele), Roxanna Baiasu (Oxford) and Mehmet Demiray (Turkey); (4-5 Nov. 2016). I also thank my seminar students, studying Hegel's moral philosophy (Autumn 2016), for discussions of these issues and of drafts of this paper. I am very grateful to the editors of this journal for their kind interest in, and support of my heterodox research. Final revisions were generously supported by the Boğaziçi Üniversitesi Research Fund (BAP), grant code: 9761. 
Burge, Tyler, 2010. Origins of Objectivity. Oxford, The Clarendon Press.

Caird, Edward, 1889. The Critical Philosophy of Immanuel Kant, 2 vols. Glasgow, Maclehose.

Carnap, Rudolf, 1950a. Logical Foundations of Probability. Chicago, University of Chicago Press.

-_-, 1950b. 'Empiricism, Semantics, and Ontology'. Revue International de Philosophie 4:20-40; $2^{\text {nd }}$ rev. ed. in: Carnap (1956), 205-221.

---, 1956. Meaning and Necessity, $2^{\text {nd }}$ rev. ed. Chicago, University of Chicago Press.

Carroll, Lewis, 1895. 'What the Tortise Said to Achilles.' Mind 4:278-280.

Chisholm, Roderick, 1982. The Foundations of Knowing. Minneapolis, University of Minnesota Press.

Conklin, William, 2008. Hegel's Laws: The Legitimacy of a Modern Legal Order. Stanford University Press.

Curren, Randall, and Ellen Metzger, 2017. Living Well Now and in the Future: Why Sustainability Matters. Cambridge, Mass., MIT Press.

Daniels, Norman, 1996. Justice and Justification: Reflective Equilibrium in Theory and Practice. Cambridge, Cambridge University Press.

Dewey, John, 1938. 'Means and Ends: Their Interdependence, and Leon Trotsky's Essay, "Their Morals and Ours"'. New International 4 (August 1938):232-233; rpt. in: J.A. Boydson, ed., The Later Works of John Dewey (Carbondale, Ill.: Southern Illinois University Press, 1988), 13:349-354.

Erickson, Paul, Judy Klein, Lorraine Daston, Rebecca Lemov, Thomas Sturm and Michael Gordin, 2013. How Reason almost lost its Mind: The Strange Career of Cold War Rationality. Chicago, University of Chicago Press.

Falkenheim, Hugo, 1909. „Eine unbekannte politische Druckschrift Hegels“. Preussische Jahrbücher 138.11:193-220; rpt. in: H. Schneider \& N. Waszek, eds., Hegel in der Schweiz (1793-1796) (Frankfurt am Main: Lang, 1997), 261-286.

Forst, Rainer, 2007. Recht auf Rechtfertigung. Frankfurt am Main, Suhrkamp; Engl. tr.: idem. (2012).

-—-, 2011. Kritik der Rechtfertigungsverhältnisse. Berlin, Suhrkamp; Engl. tr.: idem. (2014).

---, 2012. J. Flynn, tr., The Right to Justification. New York, Columbia University Press.

- - , 2014. C. Cronin, tr., Justification and Critique: Towards a Critical Theory of Politics. Cambridge, Polity.

Frege, Gottlieb, 1879. Begriffschrift, eine der arithemetischen Nachgebildete Formelsprache des reinen Denkens. Halle (Saale), Nebert.

Gareis, Karl, 1911. Introduction to the Science of Law: Systematic Survey of the Law and Principles of Legal Study. Boston, The Boston Book Company.

Goodman, Nelson, 1955. Fact, Fiction, and Forecast, $4^{\text {th }}$ ed. 1983. Cambridge, Mass., Harvard University Press.

Griffin, James, 1996. Value Judgment: Improving our Ethical Beliefs. Oxford, Clarendon Press.

Hegel, G.W.F. 1986-2013. Gesammelte Werke, 31 vols. Deutsche Forschungsgemeinschaft, with the Hegel-Kommission der Rheinisch-Westfälischen Akademie der Wissenschaften and the Hegel-Archiv der Ruhr-Universität Bochum. Hamburg, Meiner; cited as ' $G W$ ' by volume:page.line numbers. Individual works are indicated by their German initials. Volumes 23-31 contain lecture manuscripts or transcripts; these are cited as 'Vor.' by volume:page numbers.

---, 1798a. [Anon.] Aus den vertraulichen Briefen über das vormalige staatsrechliche Verhaltnis des Waadtlandes (Pays de Vaud) zur Stadt Bern. Frankfurt am Mein, Jäger. GW 2:387-582; Engl. tr. (exerpt) in: idem. (2002), 123-133. 
- - , 1798b. (Ms. Fragment) „Daß die Magistrate von den Bürgern gewählt werden müssen“/ „Über die neuesten inneren Verhältnisse Württembergs, besonders über die Gebrechen der Magistratsverfassung". GW 2:99-110; Engl. tr. in: idem. (1964), 243-245; and idem. (1999), 1-5.

- - , 1799-1803. „Die Verfaßung Deutschlands“(„Sollte das politische Resultat [...]“). GW 5:1-126; Engl. tr. in: idem. (1964), 143-242; and idem. (1999), 6-100.

---, 1807. Die Phänomenologie des Geistes. Bamberg \& Würzburg, Goephard; W. Bonsiepen \& R. Heede, eds., GW 9.

- - , 1817. „Verhandlungen in der Versammlung der Landstände des Königreichs Württemberg im Jahr 1815 und 1816". Heidelbergische Jahrbücher der Literatur 10.66-68:1041-1088, 10.73-77:1153-1232; GW 15:30-125; Engl. tr. in: idem. (1964), 246-294; and idem. (2009), 32-136.

-- , 1821. Grundlinien der Philosophie des Rechts oder Naturrecht und Staatswissenschaft im Grundrisse. Berlin, Nicolai; abbreviated 'Rph', cited by main sections $(\$)$ or by Hegel's published Remarks ( $\$ n \mathrm{R}) ; G W 14$.

-_-, 1831. „Über die englische Reformbill“. Allgemeine preußische Staats-Zeitung, 1831, Nr. 115-116, 118; second half printed and distributed privately; published complete in: idem. (1832-45), 17.2 (1835):425-470; GW 16:323-404; Engl. tr. in: idem. (1964), 143-242; and in: idem. (1999), 234-270.

---, 1832-1845. Georg Wilhelm Friedrich Hegel's Werke. Vollständige Ausgabe durch einen Verein von Freunden des Verewigten (Berlin, Duncker und Humblot), 19 vols.

---, 1964. Z.A. Pelczynski, ed., T.M. Knox, tr., Hegel's Political Writings. Oxford, The Clarendon Press.

---, 1974. K.-H. Ilting, ed., Vorlesungen über Rechtsphilosophie 1818-1831, 4 vols. Stuttgart-Bad-Cannstadt, frommann-holzboog.

--_, 1985. K-H Ilting, ed., Die Philosophie des Rechts. Die Mitschriften Wannenmann (Heidelberg 1817/18) und Homeyer (Berlin 1818/19). Stuttgart, Klett-Cotta.

-—-, 1999. L. Dickey, ed., H.B. Nisbet, tr., Political Writings. Cambridge, Cambridge University Press.

- - , 2002. J. Stewart, ed. \& tr., Miscellaneous Writings of G.W.F. Hegel. Evanston, Ill., Northwestern University Press.

---, 2008. Outlines of the Philosophy of Right. S. Houlgate, ed., T.M. Knox, tr., Oxford, Oxford University Press; abbreviated 'Rph', cited by main sections ( $\$$ ), by Hegel's published Remarks $(\$ n R)$ or very occasionally by lecture notes $(\$ n Z)($ ' $Z$ ' for ,Zusatz'); GW 14.

-- , 2009a. K. Worm, ed., Hegels Werk im Kontext, $5^{\text {th }}$ Release. Berlin, InfoSoftWare.

- - , 2009b. B. Bowman and A. Speight, eds. \& trs., Heidelberg Writings: Journal Publications. Cambridge, Cambridge University Press.

---, forthcoming (ms. 2013). The Phenomenology of Spirit, T. Pinkard, tr.. Draft bilingual translation in PDF format; cited by paragraph ( $\mathbb{I})$ numbers provided by the translator corresponding to $G W 9$.

Humboldt, Wilhelm von, 1851, Ideen zu einem Versuch, die Gränzen der Wirksamkeit des Staats zu bestimmen. Breslau, Trewendt; rpt. in: A. Leitzmann, ed., Wilhelm von Humboldts gesammelte Shriften (Berlin: Behr, 1903), 1:97-254.

- - 1969. J.W. Burrow, ed., J. Coulthard, tr. (rev.), The Limits of State Action. Cambridge, Cambridge University Press.

Jones, Charles O., 1975. Clean Air: The Policies and Politics of Pollution Control. Pittsburgh, University of Pittsburgh Press.

Kaufmann, Walter, 1951. 'The Hegel Myth and its Method'. Philosophical Review 60.4:459-486.

Levin, Michael, 2004. Mill on Civilization and Barbarism. London, Routledge. 
Lipps, Theodore, 1901. Das Selbstbewusstsein: Empfindung und Gefühl. Wiesbaden, Bergmann.

---, 1912. Grundzüge der Logik. Leipzig, Voss.

--_, 1913. Psychologische Untersuchungen, 2 vols. Leipzig, Engelmann.

Miller, Alice, 1981. Prisoners of Childhood. New York, Basic Books.

- - , 1983. For your own Good: Hidden Cruelty in Child-rearing and the Roots of Violence. New York, Farrar, Straus, Giroux.

- - , 1984. Thou Shalt not be Aware: Society's Betrayal of the Child. New York, Farrar, Straus, Giroux.

--_, 2001. The Truth will set you Free: Overcoming Emotional Blindness and Finding your true Adult Self. New York, Basic Books.

-- , 2005. The Body never Lies: The Lingering Effects of Cruel Parenting. New York, W.W. Norton.

Neuhouser, Frederick, 2000. The Foundations of Hegel's Social Theory: Actualizing Freedom. Cambridge, Mass., Harvard University Press

Olsen, Mancur, 1965. The Logic of Collective Action. Cambridge, Mass., Harvard University Press.

O’Neill, Ornoa, 2003. 'Constructivism in Rawls and Kant'. In: S. Freeman, ed., The Cambridge Companion to Rawls (Cambridge, Cambridge University Press), 347-367.

Pattaro, Enrico, 2005. The Law and the Right. Dordrecht, Springer; vol. 1 in: idem., editorin-chief, A Treatise of Legal Philosophy and General Jurisprudence (2005-2016), 13 vols.

Perlmutter, Martin, 1998. 'Moral Intuitions and Philosophical Method'. In: K. R. Westphal, ed., Pragmatism, Reason, and Norms (New York, Fordham University Press), 203-18.

Pettit, Philip, 1997. Republicanism: A Theory of Freedom and Government. Oxford, The Clarendon Press.

---, 2001. A Theory of Freedom: From the Psychology to the Politics of Agency. Oxford, Oxford University Press.

Piché, David, 1999. La Condamnation parisienne de 1277. Paris, Vrin.

Popovski, Vesselin, Gregory Reichberg and Nicholas Turner, eds., 2009. World Religions and Norms of War. Tokyo, New York, Paris, United Nations University Press.

Porter, Theodore, 1995. Trust in Numbers: The Pursuit of Objectivity in Science and Public Life. Princeton, Princeton University Press.

Powers, Lawrence, 1978. 'Knowledge by Deduction'. Philosophical Review 87.3:337-371.

Rawls, John, 1971. A Theory of Justice, $1^{\text {st }}$ ed. Cambridge, Mass., Harvard University Press.

Reidy, David, 1999. 'Rawls's Idea(l) of Public Reason'. Polis 6:93-113.

- - , 2000. 'Rawls's Wide View of Public Reason: Not Wide Enough'. Res Publica 6:49-72.

Runzo, Joseph, Nancy M. Martin, and Arvind Sharma, eds., 2003. Human Rights and Responsibilities in the World Religions. Oxford, Oneworld.

Quine, W. V. O., 1936. ‘Truth by Convention'. In: O. H. Lee, ed., Philosophical Essays for A. N. Whitehead (New York, Longman's), 90-124; rtp. in: idem. (1976), 77-106.

- - , 1976. The Ways of Paradox and Other Essays, $2^{\text {nd }}$ rev. ed. Cambridge, Mass., Harvard University Press.

Shklar, Judith, 1976. Freedom and Independence: A Study of the Political Ideas of Hegel's Phenomenology of Mind. Cambridge, Cambridge University Press.

Stewart, Jon, ed., 1996. The Hegel Myths and Legends. Evanston, Ill., Northwestern University Press.

Tempier, Étienne, 1277. 'Propositions condamnées par Étienn Tempier, évêque de Paris'. Rpt. in: H. Denifle, ed., Chartularium universitatis parisiensis (Paris, 1889), 1:543-4; 
also in: P. Mandonnett, Siger de Brabant et l'averroïsme latin au XIIIme siècle (Louvain, 1911), 2:175-191; critical ed. in: Piché (1999); English tr. by E. L. Fortin and P. D. O’Neill, in: R. Lerner and M. Mahdi, eds., Medieval Political Philosophy: A Sourcebook (New York: Free Press, 1963), 335-54.

Thomas, Alan, 2017. Republic of Equals: Predistribution \& Property-Owning Democracy. Oxford, Oxford University Press.

Truman, David B., 1951. The Governmental Process: Political Interests and Public Opinion. New York, Knopf.

Wallace, James, 2008. Norms and Practices. Ithaca, NY, Cornell University Press.

Waismann, Frederick. 1945. 'Verifiability'. Proceedings of the Aristotelian Society, Supplementary Volume 19:101-164; rpt. in: A. Flew, ed., Logic and Language: First and Second Series. (New York: Anchor, 1965), 122-151.

Watson, John, 1881. Kant and his English Critics. A Comparison of Critical and Empirical Philosophy. Glasgow, Maclehose; London and New York, Macmillan.

Weber, Max, 1922. Wirtschaft und Gesellschaft. (Grundriß der Sozialökonomik, III. Abt.) Tübingen, J.C.B. Mohr (Paul Siebeck).

Westphal, Kenneth R.,

- - , 2000. 'Hegel's Internal Critique of Naïve Realism'. Journal of Philosophical Research 25:173-229.

- - , 2002-03. „Analytischer Gehalt und zeitgenössische Bedeutung von Hegels Kritik des unmittelbaren Wissens". Jahrbuch für Hegel-Forschungen 8/9:129-143.

- - , 2004. Kant's Transcendental Proof of Realism. Cambridge, Cambridge University Press.

- - , 2010. 'Hegel, Russell ef the Foundations of Philosophy'. In: A. Nuzzo, ed., Hegel and the Analytical Tradition (New York, Continuum), 174-194.

_- - 2012. 'Norm Acquisition, Rational Judgment ef Moral Particularism'. Theory ef Research in Education 10.1:3-25; doi: 10.1177/1477878512437477.

-_-, 2013a. 'Natural Law, Social Contract and Moral Objectivity: Rousseau's Natural Law Constructivism'. Jurisprudence 4.1:48-75.

- - , 2013b. 'Kant's Cognitive Semantics, Newton's Rule Four of Natural Philosophy es Scientific Realism Today'. In: Kant and Contemporary Theory of Knowledge, Kant Yearbook 5:127-168.

- - , 2015. 'Conventionalism \& the Impoverishment of the Space of Reasons: Carnap, Quine ef Sellars'. Journal for the History of Analytic Philosophy 3.8:1-66; doi: 10.15173/jhap.v3i8.42.

-- , 2016a. How Hume and Kant Reconstruct Natural Law: Justifying Strict Objectivity without Debating Moral Realism. Oxford, The Clarendon Press.

- - , 2016b. „Hegel, Naturrecht und Moralkonstruktivismus“. Jahrbuch für Recht und Ethik/Annual Review of Law and Ethics 26:000-000.

- - , 2016c. 'The Centrality of Public Reason in Hegel's Moral Philosophy'. In: P.N. Turner es G. Gaus, eds., Public Reason in the History of Political Philosophy: Classical Sources \& Contemporary Commentaries (London \& New York, Routledge), 330-353.

- - , 2016d. 'Hegel's Natural Law Constructivism: Progressive in Principle \& in Practice'. In: S. Stein \& T. Brooks, eds., Hegel's Political Philosophy: On the Normative Significance of Method and System (Oxford: Oxford University Press), 253-279.

- - , 2016e. 'Back to the 3 R's: Rights, Responsibilities re Reasoning'. SATS - Northern European Journal of Philosophy 17.1:21-60; doi: 10.1515/sats-2016-0008.

- - , 2016f. 'Kant, Aristotle \& our Fidelity to Reason'. Studi Kantiani 29:83-102.

- - , 2016g. 'Mind, Language er Behaviour: Kant's Critical Cautions contra Contemporary Internalism er Causal Naturalism'. In: S. Babür, ed., Felsefede Yöntem/Method in Philosophy, special issue of Yeditepe'de Felsefe/Philosophy at Yeditepe (İstanbul, Yeditepe Üniversitesi Press) 10:102-149. 
- - , 2016h. 'How Kant Justifies Freedom of Agency without Transcendental Idealism'. European Journal of Philosophy DOI: 10.1111/ejop.12264.

- - , 2017. Grounds of Pragmatic Realism: Hegel's Internal Critique and Transformation of Kant's Critical Philosophy. Leiden, Brill.

- - , forthcoming. Normative Justification, Natural Law er Kant's Constructivism in Hegel's Moral Philosophy.

Will, Frederick L., 1988. Beyond Deduction: Ampliative Aspects of Philosophical Reason. London, Routledge.

Williams, Michael, 1988. 'Skepticism without Theory'. The Review of Metaphysics 41.3:547-588.

Wittgenstein, Ludwig, 1958. Philosophische Untersuchungen/Philosophical Investitations, $2^{\text {nd }}$ ed.; G.E.M. Anscombe, tr. Oxford, Basil Blackwell.

Wolff, Michael, 2009. Abhandlungen über die Prinzipien der Logik, $2^{\text {nd }}$ rev. ed. Frankfurt am Main, Klostermann.

Wundt, Wilhelm, 1907. System der Philosophie, 3 vols., 3d rev. ed. Leipzig, Engelmann. 
Kenet. R. Vestfal

Hegelovo opravdanje ljudskog prava na ne-dominaciju

Apstrakt

'Hegel' i 'ljudska prava' retko su povezivani i oznaka 'ljudska prava' retko se javlja u njegovim delima. Zaista, Hegel je kritikovan zbog izostavljanja ujedno građanskih i političkih prava. Moja pretpostavka jeste da su čitaoci tražili moderni Dekalog i da su zanemarili kako Hegel pravda svoje stavove, i stoga samo koje stavove opravdava. Filip Petit (1997) je preusmerio pažnju na republikansku slobodu. Hegel i ja se slažemo sa Petitom da je republikanska sloboda krajnje važna vrednost, ali apelovati na njenu vrednost, ili opravdavati je apelom na reflektivni ekvilibrijum, nedovoljni su i u teoriji i u praksi. Rekonstruišući Kantovu kritičku metodologiju i objašnjavajući društveni karakter racionalog opravdanja u ne-formalnim domenima, Hegel pokazuje da je republikansko pravo na ne-dominaciju konstitutivno za podjedanko republikansko pravo na opravdanje (Frost 2007) - gde su oba nužni uslovi za dovoljno racionalno opravdanje u svim ne-formalnim domenima, uključujući zahteve za prava ili imputacije dužnosti ili obaveza. To je neposredna moralna, politička i pravna implikacija Hegelove analize uzajamnog priznanja, i njegova temeljna, konstitutivna uloga u racionalnom opravdanju. Specifične posledice fundamentalnog republikanskog prava na ne-dominaciju moraju biti određene sagledavajući koji oblici nedozvoljene dominacije su mogući ili verovatni unutar bilo kog specifičnog društva, u pogledu njegovih društvenih, političkih i ekonomskih struktura i funkcionisanja.

Ključne reči: Hegel, ljudska prava, ne-dominacija, Petit, republikanizam, opravdavanje, priznanje 